\title{
Ethics of information
}

\section{A foundation shift at the library's core}

$\mathbf{O}$

ur university is considering a restructuring of its core curriculum, while anticipating the opening of a new library building in spring 2013. I have spent a great deal of time since the beginning of the spring 2011 semester talking to other libraries that have undergone a restructuring of their core to find out how the goals of the library have been integrated into their revised curriculum.

In the debate about how requirements will unfold, is a debate about the role of the library within the core curriculum. Inevitably, our library will be seeking universal ways to approach instructional design at the foundations level in an effort to move beyond the one-shot style of instruction. Right now many of the librarians at my university involved with instruction do one-shots, or an instruction session that is a one-time class (usually 50 minutes) that requires an examination of databases and their application to a particular class.

It is often the case that the application is separate from the class (not linked to an assignment) and thus not entirely meaningful and relevant to students, wondering how the library really fits into their academic life. This idea comes on the heel of testimonials from students who rarely, if ever, get to the library for in-depth research. ${ }^{1}$ Illustrating proper uses of library resources separate from an assignment, or a class, that makes the library a meaningful component in students' lives is difficult. With any luck, some of the librarians have structured their library classes as part of a series of required courses in which instruction can be designed, as opposed to introduced through disparate, impromptu instruction demonstrating use of tools.

In communicating with our campuswide core curriculum committee, and in talking with other librarians about course design, I have been re-thinking the approach to the one-shot toward a conceptual approach in advance of the curriculum overhaul. ${ }^{2}$ I am fortunate to work with many departments who allow me the creativity and vision to explore ways to involve students in the larger discussion about best ways to access and use information. For instance, I work with the Speech Communication Department in teaching a series of classes through an Introduction to Public Speaking class. I see several professors who bring their classes to the library for at least two separate library visits. Instead of conducting one-time sessions on database searching (information retrieval) I am able to work with the faculty to offer meaningful instruction that ties into a series of speech assignments assigned throughout the course of the semester. This allows me greater freedom to work with student strengths and weaknesses, and to offer more meaningful instruction.

Instead of talking strictly about databases, or employing the same talk about the virtues of library resources, I have been engaged in the design of creative modules that engage students with larger issues about information and the way it affects their lives. I have been

Zachary Newell is humanities librarian at Salem State University Library, e-mail: znewell@salemstate.edu () 2012 Zachary Newell 
able to create a series of "Ethics of Information" modules that communicate concepts to the Speech classes, but are also universally applicable to other departments to which I am a liaison. The shift away from traditional library instruction pays dividends in communicating a new age of information to a new age of students. Although recent studies have provided data on students research habits as depending too much on Google, clearly there is an interest in communicating to students the way Google works, or ethical questions about Facebook, or why students should know about issues surrounding privacy and the proliferation of images online. Such discussions and lessons go a long way in communicating the immediacy of information instruction, or what I have been calling Ethics of Information classes.

Here are three examples of the way I have been conducting classes, tailored for a variety of courses.

Google vs. The Library: Transitioning Your (Re)Search. I explore effective ways to get students to think about the way they access and use information, including discussion about Google, "Filter Bubbles," and politics.

Rip and Wrap, Beware! I also explore creative ways to talk about plagiarism, including video and discussion about pop culture, while employing strategies for getting the class involved in the discussion.

Online Tracks: Visualizing Your Footprint. I also explore the topic of visual literacy, the power of images and tales and cautions about using and proliferating images online (leaving a digital footprint).

I am able to use any or all of these classes with separate visits from one course, but I can also use any aspect of the Ethics of Information design to apply to a specific course. For instance, even though I have used my Google talk to introduce art history students to Filter Bubbles, I have also used my Visual Literacy talk to discuss the power and trials of using images online in both a Speech and Art course. In both cases I am making a strong and immediate impact with students who appreciate the way information (outside of the library) impacts what they do on a daily basis, while making a case for using the library resources.

In many cases I spend the last quarter of classes making a parallel connection with what we have been talking about during class and its applications to library resources. I am a little ambivalent about promoting the use of databases since what is found online is quite different in many cases from what is found in the library (That's the point, right?) I debate my own ethical relationship to the teaching of resources and what the students need to know about information and their relationship to that information. I ask the question to myself: what will students do when they do not have access to a healthy, albeit pricey, collection of resources purchased through their library? This question was posed in a talk recently given by Harvard University Law Professor Lawrence Lessig. Lessig pondered the gap between what could be found on the Internet (for a price) and what could be found through subscription to a well-sourced university library. ${ }^{3}$

While I carry through with the discussion, I wonder if I am promoting an unrealistic reality for students by teaching library resources. Perhaps I am only making myself feel better, but it is why universal design for something like the Ethics of Information is all the more important in getting students to think about information and its impact on their lives, rather than instruct exclusively to resources that, while always changing based on funds available to purchase them, might not be available or used anyway, at least not at the foundation level of a students' academic journey. Reaching students and bridging the gap becomes the goal in shifting design. As our university shifts the conversation and reality about the revision of its new core, this is a dialogue that will continue to take place between faculty, students, and librarians. Where we all stand in relation to the library and the future of questions around information is an issue that will certainly transcend the library

(continued on page 445) 
Lydia Welhan has been appointed technical services librarian at Saddleback College, effective August 13, 2012.

\section{Retirements}

Kate Hickey has retired after 16 years as dean and university librarian at Elon University in

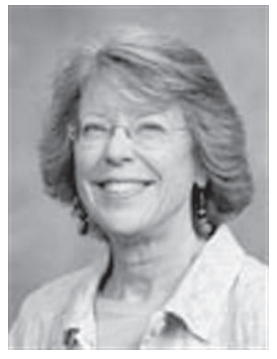

Kate Hickey Elon, North Carolina, following a career spanning more than four decades. In 2000, Hickey was instrumental in the design of Elon's new library, which integrated the learning commons model throughout the building's first floorone of the first such commons at four-year institutions. Hickey served on the Librarians Governing Council of NC LIVE (North Carolina's virtual library)

("Ethics ..., , cont. from page 413)

and its new building. I am using every opportunity to start the conversation now.

\section{Notes}

1. Liz Dwyer, "Just Google It: How Search Engines Stunt College Students' Research Skills," Good Education, www.good.is, http://www. good.is/post/just-google-me-why-the-search -engine-might-be-stunting-college-students -research-skills/ (accessed June 13, 2012). for six years, was a founding member of the Triad Academic Libraries Association, and was a member of the Advisory Board of the University of North Carolina-Greensboro School of Library and Information Science. She has been active in ACRL, CLS, and CJCLS committees and programs for 27 years. She was a member of the Joint ACRL/LAMA Designing Academic Libraries and Learning Spaces Guide Task Force that published a wiki for practicing architects and was the coauthor of Collection Management in the Electronic Age, CJCLS's first published monograph. She was an active participant in the College Library Directors Mentoring Program, first as a participant and later as a mentor to five new library directors. Prior to her tenure at Elon, Hickey was director of the Shuman Library at the Pennsylvania College of Technology for 13 years. Her varied career included work at the National Fisheries Research and Development Laboratory in Wellsboro, Pennsylvania, and as an adult and children's librarian at two public libraries. $\boldsymbol{n}$

2. I would like to give special thanks to Sarah Faye Cohen, former assistant director of the Miller Information Commons at Champlain College, for graciously sharing her ideas, enthusiasm, and approaches to creatively engaging students in the classroom.

3. Lawrence Lessig, "The Architecture of Access to Scientific Knowledge," CERN Colloquium and Library Science Talk, http://cdsweb.cern.ch/ from http://vimeo. com/22633948 (accessed June 13, 2012). n

("New Publications," cont. from page 441)

The Wizard of $\mathrm{Oz}$ As American Myth, by Alissa Burger (230 pages, March 2012), looks at six different expressions of L. Frank Baum's uniquely American fairy tale, The Wonderful Wizard of Oz: the original novel (1900), the MGM classic movie (1939), Sidney Lumet's film musical The Wiz (1978), Gregory Maguire's novel Wicked: The Life and Times of the Wicked Witch of the West (1995), Stephen Schwartz and Winnie Holzman's Broadway hit Wicked: A New Musical (2003), and the SyFy Channel miniseries Tin Man (2007). From Baum's original conception of $\mathrm{Oz}$ as the American frontier, Burger follows the transformations of the myth into shifting representations of gender, metaphors of race and otherness, concepts of domestic space ("there's no place like home"), and portrayals of magic and witchcraft as either destructive or empowering. \$35.00. McFarland. 978-0-7864-6643-6. n 